\title{
X-RAY DETERMINATION OF THE STRUCTURE OF ICE IV
}

\section{By Hermann Engelhardt and Barglay Kamb}

(Division of Geological and Planetary Sciences, * California Institute of Technology, Pasadena, California 9 I 125 , U.S.A.)

\begin{abstract}
Ice IV, a wholly metastable ice phase, has a structure based on a framework of tetrahedrally hydrogen-bonded water molecules in a rhombohedral unit cell. The structure involves two non-equivalent types of water molecules and four non-equivalent types of hydrogen bonds. A novel structural feature is a hydrogen bond that passes through the center of a 6-ring of water molecules and links non-adjacent structural layers. The bond network is proton-disordered, even after quenching.

RÉsumé. Determination de la structure de la glace IV aux rayons $X$. La glace IV, qui est une phase totalement métastable a une structure correspondant à un réseau de molécules d'eau liées à leurs voisines par des liaisons hydrogène respectant la symétrie tétraédrale et à une maille élémentaire rhombohédrique. Cette structure implique 2 types de molécules d'eau et 4 types de liaisons hydrogène. Le caractère structural original est dans le fait que des liaisons hydrogène passent à travers des anneaux de 6 molécules d'eau, reliant ainsi des couches non adjacentes. Il n'y a pas d'ordre protonique dans le réseau de liaisons, même après trempe.

Zusammenfassung. Bestimmung der Struktur von Eis IV mittels Röntgenbeugung. Eis IV, eine völlig metastabile Eisphase, besitzt eine Struktur, die auf einem Gerüst von tetraedrisch über Wasserstoffbrücken gebundenen Wassermolekülen in einer rhomboedrischen Elementarzelle beruht. Die Struktur verknüpft zwei ungleichwertige Typen von Wassermolekülen und vier ungleichwertige Typen von Wasserstoffbrückenbindungen. Ein neuartiges Strukturmerkmal ist eine Wasserstoffbrückenbindung, die durch den Mittelpunkt eines Sechsrings von Wassermolekülen hindurchgeht und nicht-aneinandergrenzende Lagen der Struktur verbindet. Das Bindungsnetzwerk ist in bezug auf die Protonen ungeordnet, selbst nach Abschreckung.
\end{abstract}

ICE IV is a polymorph of ice that has no field of true stability, being metastable with respect to ice V, ice VI, and ice III in the temperature and pressure range where it can be formed, namely $c .4$ ioo to 6 ooo bar and -18 to $-7^{\circ} \mathrm{C}$ (Engelhardt and Whalley, 1972).

Its structure has been determined and refined by least-squares methods using nearlycomplete three-dimensional X-ray diffraction data from $\mathrm{D}_{2} \mathrm{O}$ single crystals quenched to $77 \mathrm{~K}$ and released to atmospheric pressure.

The structure is based on a rhombohedral cell measuring $a=760 \mathrm{pm}, \alpha=70 . \mathrm{I}^{\circ}$, and containing $\mathrm{I} 6$ water molecules. The density at atmospheric pressure and $110 \mathrm{~K}$ is 1.27 $\mathrm{Mg} \mathrm{m}^{-3}$, intermediate between that of ice $\mathrm{V}\left(\mathrm{I} .23 \mathrm{Mg} \mathrm{m}^{-3}\right)$ and ice VI (I.3 $\left.\mathrm{I} \mathrm{Mg} \mathrm{m}^{-3}\right)$.

The space group for ice IV is $R \overline{3} c$. This is the same space group as that to which the ice II structure would transform upon disordering of its ordered proton arrangement. However, the actual structure of ice IV is quite different, being based on a topologically entirely different arrangement of water molecules and hydrogen bonds.

The structure is built from two symmetrically non-equivalent kinds of oxygen atoms, $\mathrm{O}(\mathrm{I})$ in general positions $12 f$ of space group $R \overline{3} c$, and $\mathrm{O}(\mathrm{II})$ in special position $4 c$, lying on the 3 -fold axis. The atomic coordinates of the 16 oxygen atoms of the rhombohedral unit cell are given in Table I. The coordinates of $\mathrm{O}(2), \mathrm{O}(3), \ldots$, are related to those of $\mathrm{O}(\mathrm{I})$ by the symmetry transformations of space group $R_{3} c$, and the coordinates of $\mathrm{O}\left(\mathrm{I}_{4}\right), \mathrm{O}\left(\mathrm{I}_{5}\right), \ldots$, are similarly related to $\mathrm{O}(\mathrm{I} 3)$.

The structure consists of water molecules hydrogen-bonded to one another in a tetrahedral bond framework. The most interesting element of the structure, shown in Figure $\mathrm{I}$, consists of a flat-puckered, hydrogen-bonded 6-ring of water molecules, through the center of which passes a hydrogen bond between two water molecules located above and below the 6 -ring along the $c_{\mathrm{H}}$-axis. In Figures I and 2, only the oxygen atoms of the water molecules are explicitly shown, the hydrogen atoms being implicitly indicated by the hydrogen bonds, which are represented by rods connecting the oxygen atoms. Oxygen atoms of type $\mathrm{O}(\mathrm{I})$ form the puckered 6-ring in Figure 1 , while the pair of oxygen atoms lying on the 3 -fold

* Contribution No. 3010. 
TAble I. Atomic coordinates in ICE IV in Fractional Units of THE RHOMBOHEDRAL AXES

\begin{tabular}{|c|c|c|c|c|}
\hline Atom type & Atom & $x$ & $y$ & $z$ \\
\hline $\mathrm{O}(\mathrm{I})$ & $\mathrm{O}(\mathrm{I})$ & $0.3^{80}$ & -0.110 & -0.240 \\
\hline$O(I)$ & $\mathrm{O}(2)$ & $-0.24^{0}$ & $0.3^{80}$ & -O.I 10 \\
\hline$O(I)$ & $\mathrm{O}(3)$ & -o.I Io & $-0.24^{\circ}$ & $0.3^{80}$ \\
\hline $\mathrm{O}(\mathrm{I})$ & $\mathrm{O}(4)$ & $-0.3^{80}$ & 0.110 & $0.24^{\circ}$ \\
\hline $\mathrm{O}(\mathrm{I})$ & $\mathrm{O}(5)$ & 0.240 & $-0.3^{80}$ & O. I IO \\
\hline $\mathrm{O}(\mathrm{I})$ & $\mathrm{O}(6)$ & O.1IO & $0.24^{\circ}$ & $-0.3^{80}$ \\
\hline $\mathrm{O}(\mathrm{I})$ & $\mathrm{O}(7)$ & 0.260 & $0.39^{\circ}$ & 0.880 \\
\hline $\mathrm{O}(\mathrm{I})$ & $\mathrm{O}(8)$ & $0.88 \mathrm{o}$ & 0.260 & $0.39^{\circ}$ \\
\hline $\mathrm{O}(\mathrm{I})$ & $\mathrm{O}(9)$ & $0.39^{\circ}$ & 0.880 & 0.260 \\
\hline $\mathrm{O}(\mathrm{I})$ & $\mathrm{O}(\mathbf{1 0})$ & $0.74^{\circ}$ & 0.610 & O. 120 \\
\hline $\mathrm{O}(\mathrm{I})$ & $\mathrm{O}(\mathrm{I} \mathbf{I})$ & 0.120 & $0.74^{\circ}$ & 0.6 Io \\
\hline $\mathrm{O}(\mathrm{I})$ & $\mathrm{O}(12)$ & 0.6 Io & 0.120 & $0.74^{\circ}$ \\
\hline $\mathrm{O}(\mathrm{II})$ & $\mathrm{O}(13)$ & 0.085 & 0.085 & 0.085 \\
\hline $\mathrm{O}(\mathrm{II})$ & $\mathrm{O}(14)$ & -0.085 & -0.085 & -0.085 \\
\hline $\mathrm{O}(\mathrm{II})$ & $O(15)$ & $0.5^{8} 5$ & $0.5^{8} 5$ & $0.5^{8} 5$ \\
\hline $\mathrm{O}(\mathrm{II})$ & $O(16)$ & $0.4^{1} 5$ & 0.415 & $0.4^{1} 5$ \\
\hline
\end{tabular}

$c_{\mathrm{H}}$-axis, and bonding to one another through the ring center, along the axis, are of type $\mathrm{O}$ (II). The situation depicted in Figure $\mathrm{I}$, in which a hydrogen bond between two water molecules threads through the center of a ring to which the two molecules are not bonded, occurs in modified form in ice V, where the threaded ring is an 8-ring (Whalley, 1976, p. 1447). This type of structural element represents bond interpenetration without interconnection, and presages the self-clathrate feature that occurs in the denser ice phases (Kamb, [ ${ }^{\mathrm{I}}{ }_{968}$ ], p. 5 I I ).

The hydrogen bonds are of four non-equivalent kinds, of lengths (O-O distances) 279, 282, 288 , and $290 \mathrm{pm}$. Because of the bond lengths, the $\mathrm{H}$-bonds are asymmetric, the hydrogen atom in each bond lying approximately roo pm from one end of the bond or the other. The arrangement of the protons in the H-bonds is probably disordered in the same sense as that in ice I (Pauling, I96o, p. 466). The bonds of lengths 279, 282, and 290 pm must be protondisordered because of constraints of symmetry. The X-ray intensities suggest that the fourth bond, which is the type of bond forming the puckered 6-rings, is also disordered, but neutron diffraction data would be necessary to establish this with certainty. The $\mathrm{O}-\mathrm{O}-\mathrm{O}$ bond angles

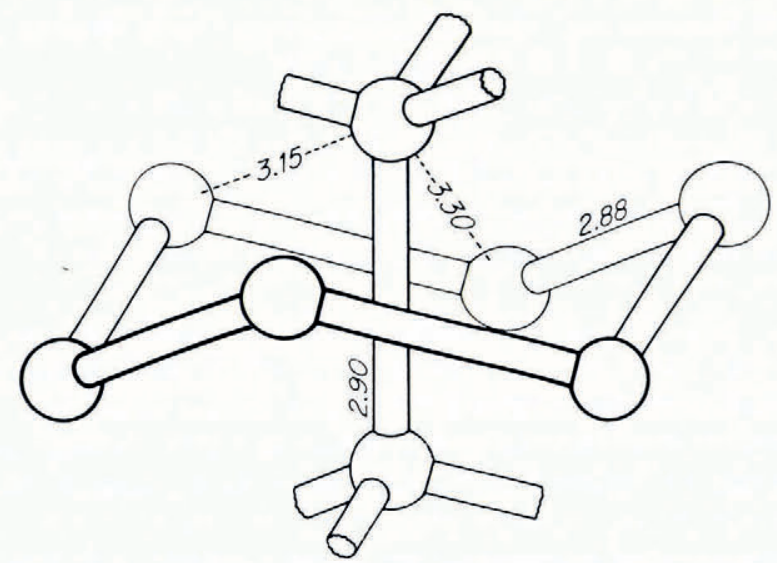

Fig. I. The essential structural element of ice IV. Oxygen atoms of type $O(I)$ form the puckered 6-ring. The balls represent oxygen atoms and the connecting sticks represent hydrogen bonds. Oxygen atoms bonded through the ring center are of type $O(I I)$. The numbers show the bond lengths and short non-bonded oxygen-oxygen distances, in aingströms. The hexagonal $c_{\mathrm{H}}$ axis is vertical, parallel to the $H$-bond between $O(I I)$-type atoms. 
formed by $\mathrm{O}(\mathrm{I})$ as apex atom range from $87.7^{\circ}$ to $127.8^{\circ}$ and those by $\mathrm{O}$ (II) from $91.8^{\circ}$ to $\mathrm{I} 24.0^{\circ}$, so that the bonding is substantially distorted from ideal tetrahedral geometry.

Figure 2 shows the structure of ice IV as viewed nearly perpendicular to the hexagonal $c_{\mathrm{H}}$-axis, this axis being tilted $10^{\circ}$ out of the plane of the drawing. The numbering of the atoms in Figure 2 is the same as in Table I. Molecular groups of the kind shown in Figure $\mathrm{I}$ can be seen, and the lateral interconnections among these groups are also visible.

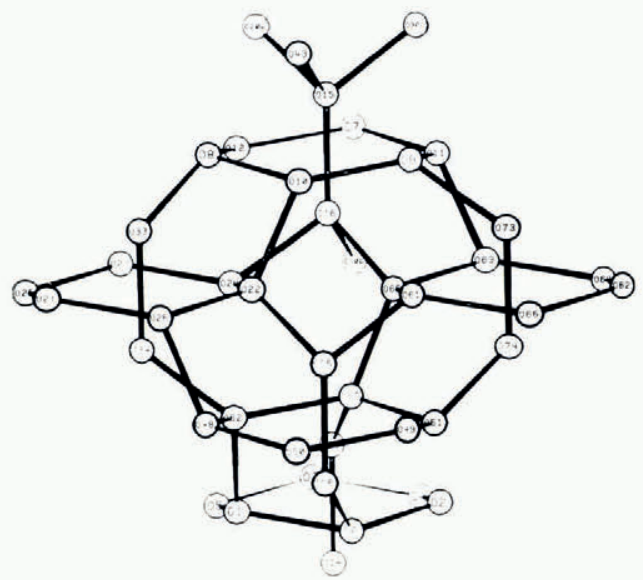

Fig. 2. Structure of ice IV. The hexagonal $c_{\mathrm{H}}$ axis is oriented vertically and is tilted about $10^{\circ}$ from the plane of the paper. Oxygen atoms $O(I)$ to $O(I G)$ are the atoms listed in Table I and represent the contents of the rhombohedral unit cell. Five structural units of the type shown in Figure $I$ are depicted in this diagram. The pairs such as $O\left(I_{5}\right)-O\left(I_{6}\right)$ are pairs of $O(I I)$-type atoms bonded parallel to the $c_{\mathrm{H}}$ axis. Groups such as $O(I)-O(6)$ and $O(7)-O(I 2)$ are puckered 6-rings of $O(I)$-type atoms.

The molecular arrangement in ice IV can be interpreted as a layer structure related in a somewhat circuitous way to ice Ic (low-pressure cubic ice). In the sense of this relationship, the bonds between pairs of $\mathrm{O}(\mathrm{II})$ atoms, passing through the 6-rings, are in fact bonds between non-adjacent layers (second-neighbor layers), rather than between immediately adjacent layers. This feature is very unusual, indeed perhaps unique, for a layer structure.

\section{Acknowledgement}

We thank Peter Pauling for providing the computer drawing of the structure of ice IV shown in Figure 2.

\section{REFERENCES}

Engelhardt, H., and Whalley, E. 1972. Ice IV. Journal of Chemical Physics, Vol. 56, No. 6, p. 2678-84.

Kamb, W. B. [ ${ }^{\mathrm{c}}{ }_{\mathrm{I}}$ 668.] Ice polymorphism and the structure of water. (In Rich, A., and Davidson, N., ed. Structural chemistry and molecular biology. San Francisco and London, W. H. Freeman and Co., p. 507-42.)

Pauling, L. I960. The nature of the chemical bond. Ithaca, N.Y., Cornell University Press.

Whalley, E. 1976. The hydrogen bond in ice. (In Schuster, P., and others, ed. The hydrogen bond. III. Dynamics, thermodynamics and special systems. Edited by P. Schuster, G. Zundel, C. Sandorfy. Amsterdam, North-Holland Publishing Co., p. 1427-70.)

\section{DISCUSSION}

J. BERTIE: Have any significant spectroscopic measurements been made on ice IV?

E. Whalley: Some years ago Dr Engelhardt measured the infrared spectrum of ice IV in Ottawa. The main conclusion was that, to the precision of the technique, the water molecules have fully disordered orientations. 